\title{
PROSES PEMBUNGAAN BEBERAPA VARIETAS Hoya coronaria DARI KAWASAN HUTAN KERANGAS AIR ANYIR, BANGKA
}

\author{
Risti Annisa'), Yulian Fakhrurrozi' ${ }^{2),}$ Sri Rahayu ${ }^{3)}$ \\ ${ }^{1}$ Mahasiswa Jurusan Biologi, FPPB, Universitas Bangka Belitung \\ email: rannisa123@gmail.com \\ ${ }^{2}$ Dosen Jurusan Biologi, FPPB, Universitas Bangka Belitung \\ ${ }^{3}$ Peneliti LIPI, Bogor
}

\begin{abstract}
Hoya coronaria found in heath forest of Air Anyir, Bangka has diverse colors. Flowers color diversity sometimes correlated varieties or the result of color changes during flowering process. The flowers development process observed from $5 \mathrm{H}$. coronaria varieties with different color from heath forest of Air Anyir, Bangka.The purpose of this research to know the flowering process and flower color change process some varieties of $H$. coronaria. This research done from September 2015-January 2016. This study used qualitative method to made detail and systematic description about flowering phase. H.coronaria flowering process consists of flower initation, flower estabilisment and flower development. Flower initation needs 13-15 days, flower estabilisment needs 10-12 days and flower development consists of early blooming process, full blooming and senescene. Early blooming process needs 1-3 days, full blooming needs 5-12 days and senescene needs 1-3 days. During the development process changes from rounded to pentagonal shape and there is a change in size. The observation result showed that 5 varieties are different from one another based on the difference between the colors of the flowers. Variety 1 has yellow corolla without honey line and deep pink corona. Variety 2 has light yellow green corolla with strong pink honey line and moderate red corona. Variety 3 has moderate red corolla with moderate red honey line and moderate red corona. Variety 4 has light yellow green corolla with moderate pink honey line and light yellow green corona. Variety 5 has moderate red without honey line and grayish red corona.
\end{abstract}

Key words: flowering process, color change, Hoya coronaria, heath forest.

\section{PENDAHULUAN}

Hoya merupakan tumbuhan epifit yang kebanyakan jenisnya merambat, dari suku Apocynaceae dan anak suku Asclepiadoideae (Rahayu 2012). Bunganya merupakan bunga majemuk yang tersusun dalam tandan berbentuk payung (umbel) (Rahayu 2001) memiliki lapisan lilin tebal mengkilap pada korona dan korolanya dengan warna bervariasi (Wantrop et al. 2006). Hoya dikenal sebagai bunga lilin dan bunga porselin oleh masyarakat Amerika Serikat dan Eropa (Mardi 2009).

Keindahan bunga Hoya yang khas pada bentuk dan warnanya membuat tumbuhan ini berpotensi dijadikan sebagai tanaman hias dengan nilai ekonomi tinggi (Rahayu 2006). Hoya dijadikan sebagai tanaman hias di
Amerika Serikat dan Eropa, meskipun Hoya bukan tumbuhan asli negara tersebut (Mardi 2009). Indonesia memiliki keanekaragam Hoya tertinggi di dunia dengan persebaran yang merata di seluruh pulau Indonesia (Kleijn \& van Donkelaar 2001). Keanekaragaman jenis Hoya yang tinggi ini membuat Indonesia berpotensi menjadi produsen Hoya dunia untuk di ekspor ke luar negeri.

Salah satu daerah yang memiliki beberapa jenis Hoya di Indonesia adalah Pulau Bangka. Namun, jenis yang telah dipublikasikan sebagai tanaman hias sampai saat ini adalah Hoya imperialis dan Hoya multiflora (bunga Rangkang) (Anggraini 2008). Salah satu jenis Hoya yang belum dipublikasikan di Pulau Bangka adalah Hoya coronaria yang banyak ditemukan di hutan kerangas. Hutan kerangas di 
Kepulauan Bangka Belitung terdapat dalam jumlah besar (Whitten et al. 1984) dengan persebaran merata di Pulau Bangka dan Pulau Belitung. Hutan kerangas merupakan komunitas vegetasi yang berkembang di tanah terdegradasi. Kawasan hutan kerangas menurut IUCN (The International Union for The Conservation of Nature) termasuk kategori rawan (Kissinger et.al 2013).

Berdasarkan survei pendahuluan yang telah dilakukan di kawasan Hutan Kerangas Air Anyir, ditemukan beberapa $H$. coronaria dengan warna bunga beranekaragam. Keanekaragaman warna bunga ini bisa menunjukkan varietas atau hanya variasi biasa dalam proses pembungaan. Proses pembungaan merupakan salah satu proses biologi yang dialami tumbuhan. Menurut Rahayu et al. (2007) selama proses pembungaan dapat diketahui proses biologi waktu bunga mekar, lama bunga mekar, jumlah bunga mekar dan perkembangan bunga dari calon kuncup sampai gugur. Melalui proses pembungaan pada perkembangan bunga dapat diketahui lebih detail adakah perubahan warna bunga $H$. coronaria yang dapat menunjukkan perbedaan varietas. Berdasarkan hal tersebut perlu dilakukan penelitian mengenai proses pembungaan yang meliputi tahapan pembungaan dan perubahan warna pada beberapa varietas $H$. coronaria di Pulau Bangka. Hasil dari penelitian yang telah dilakukan diharapkan dapat menjadi data dan informasi awal mengenai tahap-tahap pembungaan dan perubahan warna untuk mengetahui keanekaragaman varietas $H$. coronaria yang berpotensi untuk dibudidayakan.

\section{METODE PENELITIAN}

Lokasi pengambilan kuncup $H$. coronaria dilakukan di Hutan Kerangas Air Anyir, Bangka kemudian dipindahkan dan diadaptasikan di rumah percobaan Jalan Fatmawati Raya, Pangkalpinang. Pemindahaan H. coronaria dilakukan karena pada habitat aslinya di Hutan Kerangas Air Anyir telah mengalami alih-fungsi menjadi kawasan industri. Alih-fungsi ini membuat habitat $H$. coronaria digusur dan dibakar. Pengamatan terhadap proses pembungaan $H$. coronaria dilakukan di rumah percobaan yang diletakkan di bawah naungan. Pengukuran $\mathrm{pH}$ tanah di lakukan di Laboratorium MIPA Fakultas Pertanian, Perikanan dan Biologi Universitas Bangka Belitung. Penelitian ini dilaksanakan pada bulan September-Desember 2015.

\section{Prosedur Penelitian}

Penelitian ini dilaksanakan dengan metode kualitatif yaitu dengan membuat deskripsi secara detail dan sistematis tentang fase-fase pembungaan 5 varietas $H$. coronaria.

\section{Pengamatan perkembangan bunga}

Perkembangan bunga diamati mulai dari munculnya kuncup pada tandan bunga sampai bunga mekar sempurna hingga bunga gugur. Perkembangan tersebut dicirikan dengan perubahan bentuk, ukuran dan warna bunga (Hidayat 2010). Pengamatan pembungaan meliputi jumlah kuncup bunga per tandan, jumlah bunga mekar serta waktu bunga mekar yang meliputi saat dan lama bunga mekar sampai bunga rontok (Rahayu et al. 2007). Pengamatan juga dilakukan terhadap warna bunga bagian atas dan bawah dari mulai bunga kuncup, mekar, mekar sempurna dan rontok. Penentuan warna bunga dilakukan dengan menggunakan color chart dari buku Munsell Color Chart for Plant Tissue. Diameter kuncup diukur dengan jangka sorong dan panjang tangkai kuncup bunga diukur dengan penggaris. Pengamatan dilakukan setiap hari terhadap 5 varietas $H$. coronaria terpilih dengan jumlah kuncup setiap varietas minimal 1 dan pengukuran diameter kuncup dan panjang tangkai kuncup bunga dilakukan setiap 7 hari sekali.

\section{Pengukuran faktor lingkungan}

Pengukuran faktor lingkungan meliputi pengukuran suhu, kelembaban udara dan intensitas cahaya (Rahayu et al. 2007) serta dilakukan pengukuran $\mathrm{pH}$ tanah media tanam H. coronaria. Suhu dan kelembaban udara diukur menggunakan termohigrometer. Intensitas cahaya diukur menggunakan luxmeter. Pengukuran suhu udara, kelembaban udara dan intensitas cahaya dilakukan setiap 
hari pagi pukul 08.00 WIB dan sore pukul 16.00 WIB dengan ulangan sebanyak 3 kali.

Pengukuran $\mathrm{pH}$ tanah menggunakan $\mathrm{pH}$ meter. Metode pengukuran yang dilakukan adalah tanah sebanyak $5 \mathrm{~g}$, dimasukkan ke dalam botol lalu ditambahkan $5 \mathrm{~mL}$ akuades. Tanah yang sudah ditambahkan akuades didiamkan selama 5 menit dan dihomogenkan selama 1 jam. Kemudian dilakukan pengukuran menggunakan $\mathrm{pH}$ meter. Sebelum melakukan pengukuran $\mathrm{pH}$ meter dikalibrasi terlebih dahulu menggunakan larutan buffer ( $\mathrm{pH} 4$ dan 7) (Mindari \& Priyadarsini 2011).

\section{HASIL DAN PEMBAHASAN}

\section{Proses Pembungaan Varietas H. coronaria}

Pembungaan merupakan proses

pembentukan alat reproduksi pada tumbuhan dimana umumnya pembungaan terjadi di bagian meristem ujung. Tyas et al. (2013) menyebutkan pada pembungaan terjadi proses perubahan apeks vegetatif menjadi apeks reproduktif. Proses pembungaan menurut Arteca (1995) terdiri dari beberapa tahap yaitu inisiasi bunga, pembentukan bunga dan perkembangan bunga.

Tabel 1. Lama dan fase pembungaan $H$. coronaria.

\begin{tabular}{ll}
\hline Fase pembungaan & Waktu \\
\hline Inisiasi bunga & $13-15$ hari \\
Pembentukan bunga & $10-12$ hari \\
Perkembangan bunga & \\
$\quad$ Mulai mekar & $1-3$ hari \\
$\quad$ Mekar sempurna & $5-12$ hari \\
Rontok & $1-3$ hari \\
\hline
\end{tabular}

- Insiasi bunga

Inisiasi bunga ditandai dengan munculnya kuncup pada bakal tangkai bunga sampai fase awal kuncup kecil yaitu membentuk struktur klaster bunga mejemuk (Jamsari et al. 2007). Proses inisiasi bunga $H$. coronaria memiliki rentang hari antara 13-15 hari (Tabel 1). Kuncup bunga $H$. coronaria berbentuk bulat dengan korola yang menutupi korona sementara bagian kelopak bunga (calyx) berukuran sangat kecil terletak di bawah korola. Hal ini menyebabkan ketika kuncup, bagian yang membuka adalah bagian korola bukan kelopak bunga. Pada bunga lain saat inisiasi bunga terjadi menurut Hidayat (2010) bagian kelopak bunga akan menutupi korola yang perlahan membuka dan bergeser ke bagian dasar bunga.

\section{- Pembentukan bunga}

Pembentukan bunga adalah tahap ketika bagian bunga mulai terlihat membentuk asesori bunga (Arteca 1995). Tahapan ketika bagian bunga mulai terlihat pada $H$. coronaria dilihat pada tahapan kuncup besar. Rentang hari pembentukan kuncup besar adalah antara 10-12 hari (Tabel 1). Pada tahapan ini terjadi perubahan bentuk kuncup awal yang berbentuk bulat menjadi segi lima serta adanya pertambahan ukuran. Jamsari et al. (2007) menyatakan pada fase kuncup besar ditandai dengan keluarnya bakal mahkota bunga/korola dari bakal kuntum. Kuncup besar H. coronaria tidak ditandai dengan keluarnya bakal korola, tetapi ketika korola bunga telah mengalami perubahan bentuk menjadi segi lima.

\section{- Perkembangan bunga}

Menurut Arteca (1995) perkembangan bunga adalah proses perubahan bentuk terbentuknya bunga sampai mekar. Pada bunga $H$. coronaria perkembangan bunga dilihat dari proses bunga mulai mekar, mekar sempurna dan rontok. Proses bunga mulai mekar $H$. coronaria memiliki rentang hari 1-3 hari di saat suhu rendah dan kelembaban tinggi (Tabel 2). Pada proses ini bagian korola atas mulai membuka helai korola satu persatu. Bentuk bunga dilihat dari samping berbentuk sedikit melengkung. Hidayat (2010) menyatakan pada tahapan bunga mekar ditandai dengan membukanya mahkota bunga dibagian ujung sampai mencapai pembukaan maksimal

Bunga $H$. coronaria memiliki rentang hari mekar sempurna selama 5-12 hari (Tabel 1). Keadaan mekar sempurna pada $H$. coronaria dilihat dari korola yang telah terbuka sempurna. Warna pada bunga memiliki intensitas yang lebih pekat dibandingkan dengan bunga yang mulai mekar. Bentuk bunga dilihat dari samping terlihat mendatar. $H$. coronaria memiliki rentang waktu mekar yang lama dibandingkan dengan hasil penelitian Rahayu et 
al. (2007) pada $H$. lacunosa yang memiliki rentang waktu mekar 3-4 hari.

Proses rontok pada $H$. coronaria memiliki rentang hari 1-3 hari dengan karakteristik proses rontok yang berbeda (Tabel 1). Berdasarkan hasil penelitian proses rontoknya bunga $H$. coronaria terdiri menjadi dua. Pertama bunga menguning lalu langsung rontok dan lepas dari tangkai bunga. Kedua bunga kembali menguncup seperti kuncup, menghitam dan lepas dari tangkai bunga. Salah satu proses rontok bunga $H$. coronaria memiliki kesamaaan dengan proses rontoknya bunga $H$. lacunosa. Berdasarkan hasil penelitian Rahayu et al. (2007) pada H. lacunosa proses rontok ditandai dengan tangkai bunga yang menguning dan bagian bawah mahkota meregang, kemudian bunga lepas.

Selama proses perkembangan bunga dari mulai mekar sampai rontok terjadi perubahan warna. Warna bunga saat mekar sempurna lebih pekat dibandingkan dengan saat mulai mekar. Kepekatan warna terdapat pada korona dan korola bunga. Saat memasuki tahap rontok terjadi pemudaran warna baik pada korona dan korola. Pemudaran warna bunga juga diikuti dengan perubahan warna bunga menjadi hitam dan kemudian rontok. Perubahan warna bunga yang memudar pada tahap rontok diduga berkaitan dengan meningkatnya kadar etilen. Peningkatan kadar etilen diduga juga menyebabkan lepasnya korola dari tangkai bunga yang disebabkan ikatan antar sel korola dan tangkai bunga meregang. Stead (1992) selama proses senescence atau rontok akan terjadi peningkatan kadar etilen yang menyebabkan terjadinya perombakan komponen sel dan degradasi antosianin sehingga warna bunga memudar.

\section{Pengaruh Faktor Lingkungan Terhadap Proses Pembungaan}

Proses pembungaan dipengaruhi oleh faktor lingkungan yang mempengaruhi proses pembentukan kuncup dan proses mekarnya bunga. Proses pembentukan kuncup bunga diduga dipengaruhi oleh intensitas cahaya matahari. Tumbuhan memerlukan cahaya matahari yang berlimpah untuk membentuk kuncup. Schmidt (2000 dalam Hidayat 2010) menyatakan bahwa cahaya matahari yang berlimpah memacu proses pembungaan.

Cahaya matahari sangat diperlukan dalam fotosisntesis. Energi yang dihasilkan dari fotosintesis digunakan untuk proses pembentuan kuncup. Sandra (2005) saat tumbuhan berbunga seluruh hasil fotosintesis dan cadangan makanan yang ada dalam tumbuhan akan digunakan untuk proses pembungaan.

Bunga $H$. coronaria mekar pada saat suhu rendah dan kelembaban tinggi Saat suhu rendah dan kelembaban tinggi, uap air yang terkandung di udara lebih banyak. Hal ini diduga menyebabkan tumbuhan tidak perlu melakukan suatu antisipasi untuk mencegah pengupan. Graciosa (2009) menyebutkan suhu yang tinggi dapat menghambat mekar bunga, karena dengan menunda proses mekarnya bunga dapat mencegah penguapan air. Pada proses pembungaan $\mathrm{pH}$ dapat mempengaruhi terbentuknya warna bunga. Pigmen pemberi warna bunga terdiri dari antosianin yang memberikan warna merah, merah tua, biru serta merah kebiruan dan antosantin yang memberikan warna kuning gading sampai kuning tua (Henuhili 2007). Pada keadaan pH yang asam atau basa dapat mempengaruhi kestabilan warna yang dihasilkan oleh pigmen pemberi warna (Basuki et al. 2005). Henuhili (2007) menyebutkan di keadaan asam antosianin menghasilkan warna merah dan biru dalam keadaan basa sedangkan antosantin menghasilkan warna kuning tua di keadaan basa.

Tabel 2. Faktor lingkungan lokasi penelitian

\begin{tabular}{lcccc}
\hline \multirow{2}{*}{ Faktor } & \multicolumn{2}{c}{ Pagi } & \multicolumn{2}{c}{ Sore } \\
\cline { 2 - 5 } \multicolumn{1}{c}{ Lingkungan } & $\mathrm{R}$ & $\mathrm{T}$ & $\mathrm{R}$ & $\mathrm{T}$ \\
\hline Suhu $\left({ }^{\circ} \mathrm{C}\right)$ & 26 & 32 & 27,9 & 31 \\
Kelembaban $(\%)$ & 76 & 92 & 78 & 89 \\
I. Cahaya (lux) & 669 & 53700 & 3040 & 16030 \\
pH & 5,7 & 6,3 & & \\
\hline
\end{tabular}

Ket. R: Terendah; T: Tertinggi

\section{Analisis Perbedaan Proses Perkembangan Bunga 5 Varietas $H$. coronaria}

Hasil penelitian dari 5 varietas $H$. coronaria yang diamati proses perkembangannya terdapat perbedaan. Perbedaan tersebut dapat dianalisis sebagai 
berikut yaitu tingkat kerberhasilan jumlah bunga mekar dan jumlah kuncup yang muncul, waktu terjadi pembungaan dan lama hari pembungaan, perbedaan ukuran dan bentuk kuncup, serta perubahan warna bunga ketika bunga ketika kuncup sampai rontok.

- Tingkat keberhasilan jumlah bunga mekar dari jumlah kuncup yang muncul

Jumlah kuncup yang muncul tidak semua berhasil mekar pada semua varietas. Varietas 1 jumlah kuncup yang muncul 4 kuncup dan berhasil mekar 2 bunga. Varietas 3 jumlah kuncup muncul 4 kuncup dan berhasil mekar 2 bunga. Varietas 3 jumlah kuncup muncul 5 dan berhasil mekar 2 bunga. Varietas 4 jumlah kuncup muncul 3 dan berhasil mekar 2 . Varietas 5 jumlah kuncup muncul 2 dan berhasil mekar 1 .

Tabel 3. Jumlah kuncup bunga dan bunga mekar dari lima varietas $H$. coronaria

\begin{tabular}{lccc}
\hline & & \multicolumn{2}{c}{ Jumlah } \\
\cline { 3 - 4 } No & Varietas & $\begin{array}{c}\text { Kuncup } \\
\text { bunga }\end{array}$ & $\begin{array}{c}\text { Bunga } \\
\text { mekar }\end{array}$ \\
\hline 1 & Varietas 1 & 4 & 2 \\
2 & Varietas 2 & 4 & 2 \\
3 & Varietas 3 & 5 & 2 \\
4 & Varietas 4 & 3 & 2 \\
5 & Varietas 5 & 2 & 1 \\
\hline
\end{tabular}

Hal yang diduga mempengaruhi perbedaan jumlah kuncup yang muncul dan berhasil mekar adalah ketersedian energi pada tumbuhan tersebut. Ashari (1998) pada proses pembungaan bagian meristem yang biasanya menghasilkan daun dan cabang menjadi menghasilkan bunga. Proses ini memerlukan energi yang besar. Ardie (2006) pucuk yang sedang mengalami proses pembungaan membutuhkan energi yang besar untuk proses pembelahan sel. Ketidaksediaan energi yang cukup dapat menyebabkan terjadinya kegagalan perkembangan bunga sehingga, tidak semua kuncup yang terbentuk dapat mekar.

- Waktu terjadi pembungaan dan lama hari pembungaan.

Setiap varietas menunjukkan waktu terjadi pembungaan yang berbeda-beda. Hasil menunjukkan varietas yang paling awal berbunga adalah varietas 1, Varietas 2, varietas 3 , varietas 4 dan varietas 5 . Perbedaan waktu berbunga diduga dipengaruhi oleh waktu kuncup muncul. Kuncup yang pertama kali muncul akan mekar menjadi bunga yang pertama kali. Hal ini sesuai dengan Hidayat (2010) yang menyatakan bahwa kuncup yang pertama muncul akan mekar pertama (Tabel 4).

Tabel 4. Waktu terjadinya tahap pembungaan lima varietas $H$. coronaria

\begin{tabular}{|c|c|c|c|c|c|c|c|c|c|c|c|c|c|c|c|c|}
\hline \multirow{3}{*}{ Var. } & \multicolumn{16}{|c|}{ Waktu perkembangan bunga dalam minggu } \\
\hline & \multicolumn{4}{|c|}{$\begin{array}{c}\text { Oktober } \\
2015 / \text { minggu }\end{array}$} & \multicolumn{4}{|c|}{$\begin{array}{c}\text { November } \\
2015 / \text { minggu }\end{array}$} & \multicolumn{4}{|c|}{$\begin{array}{c}\text { Desember } \\
2015 / \text { minggu }\end{array}$} & \multicolumn{4}{|c|}{$\begin{array}{c}\text { Januari } \\
\text { 2016/minggu }\end{array}$} \\
\hline & 1 & 2 & 3 & 4 & 1 & 2 & 3 & 4 & 1 & 2 & 3 & 4 & 1 & 2 & 3 & 4 \\
\hline 1 & & & & & & & & & & & & & & & & \\
\hline 2 & & & & & & & & & & & & & & & & \\
\hline 3 & & & & & & & & & & & & & & & & \\
\hline 4 & & & & & & & & & & & & & & & & \\
\hline 5 & & & & & & & & & & & & & & & & \\
\hline
\end{tabular}

Keterangan:

Kuncup

Mekar sempurna
Kuncup besar

Rontok 
Lama hari perkembangan bunga setiap varietas berbeda, begitu juga dengan antar kuncup dalam satu varietas. Varietas dengan perkembangan kuncup terlama adalah varietas 3 kuntum 2 yaitu 15 hari. Varietas dengan perkembangan kuncup besar terlama varietas 3 kuntum 1 dan varietas 4 kuntum 2 selama 12 hari. Varietas dengan mulai mekar terlama varietas 3 kuntum 1 dan 2 selama 3 hari.
Varietas dengan mekar sempurna terlama varietas 4 kuntum 1 selama 12 hari. Varietas dengan waktu rontok terlama varietas 1 kuntum 1 dan 2 yaitu 3 hari. Perbedaan lama hari perkembangan bunga diduga dipengaruhi oleh ketersediaan energi pada setiap varietas yang berbeda-beda. Tyler (2001) perbedaan fase pembungaan dipengaruhi oleh ketersediaan dan pemulihan energi serta sumber lain yang digunakan dalam pembungaan (Tabel 5)

Tabel 5. Lama hari perkembangan bunga dari kuncup sampai rontok dari lima varietas H.coronaria

\begin{tabular}{|c|c|c|c|c|c|c|}
\hline \multirow[t]{2}{*}{ Var. } & \multirow[t]{2}{*}{ Kuntum } & \multicolumn{4}{|c|}{ Lama hari } & \multirow[b]{2}{*}{$\mathbf{R} *$} \\
\hline & & $\mathbf{K}^{*}$ & $\mathbf{K B}^{*}$ & MM* & MS* & \\
\hline \multirow{2}{*}{1} & 1 & 14 & 10 & 2 & 8 & 3 \\
\hline & 2 & 14 & 10 & 2 & 8 & 3 \\
\hline \multirow{2}{*}{2} & 1 & 14 & 10 & 1 & 5 & 1 \\
\hline & 2 & 14 & 11 & 1 & 7 & 1 \\
\hline \multirow{2}{*}{3} & 1 & 13 & 12 & 3 & 9 & 1 \\
\hline & 2 & 15 & 11 & 3 & 9 & 1 \\
\hline \multirow{2}{*}{4} & 1 & 14 & 10 & 1 & 12 & 1 \\
\hline & 2 & 13 & 12 & 2 & 5 & 1 \\
\hline 5 & 1 & 13 & 10 & 1 & 7 & 1 \\
\hline
\end{tabular}

Keterangan: K= Kuncup, $\mathrm{KB}=$ Kuncup Besar, MM= Mulai Mekar, MS= Mekar Sempurna, R=Rontok

Tabel 6. Perubahan ukuran kuncup bunga selama empat minggu

\begin{tabular}{|c|c|c|c|c|c|c|c|c|c|c|c|c|c|}
\hline \multirow{3}{*}{ Var. } & \multirow{3}{*}{ Kuntum } & \multicolumn{12}{|c|}{ Minggu ke } \\
\hline & & \multicolumn{3}{|c|}{1} & \multicolumn{3}{|c|}{2} & \multicolumn{3}{|c|}{3} & \multicolumn{3}{|c|}{4} \\
\hline & & $\begin{array}{c}\mathbf{P} \\
(\mathbf{c m})\end{array}$ & $\begin{array}{c}\mathrm{D} \\
(\mathrm{cm})\end{array}$ & Bentuk & $\begin{array}{c}\mathbf{P} \\
(\mathbf{c m})\end{array}$ & $\begin{array}{c}\mathrm{D} \\
(\mathrm{cm})\end{array}$ & Bentuk & $\begin{array}{c}\mathbf{P} \\
(\mathrm{cm})\end{array}$ & $\begin{array}{c}D \\
(\mathbf{c m})\end{array}$ & Bentuk & $\begin{array}{c}\mathbf{P} \\
(\mathbf{c m})\end{array}$ & $\begin{array}{c}D \\
(\mathrm{~cm})\end{array}$ & Bentuk \\
\hline \multirow{2}{*}{1} & 1 & 0,6 & 0,1 & Bulat & 0,8 & 0,6 & Bulat & 1,4 & 1 & Segilima & 1,8 & 1,3 & Segilima \\
\hline & 2 & 0,4 & 0,1 & Bulat & 0,6 & 0,6 & Bulat & 1,2 & 0,8 & Segilima & 1,6 & 1,1 & Segilima \\
\hline \multirow{2}{*}{2} & 1 & 0,6 & 0,1 & Bulat & 0,8 & 0,5 & Bulat & 1,3 & 0,9 & Segilima & 1.7 & 1 & Segilima \\
\hline & 2 & 0,4 & 0,1 & Bulat & 0,6 & 0,5 & Bulat & 1,2 & 0,7 & Segilima & 1,6 & 0,9 & Segilima \\
\hline \multirow{2}{*}{3} & 1 & 0,5 & 0,2 & Bulat & 0,7 & 0,4 & Segilima & 1,5 & 1,3 & Segilima & 1,8 & 1,4 & Segilima \\
\hline & 2 & 0,5 & 0,2 & Bulat & 0,7 & 0,4 & Segilima & 1,6 & 1,4 & Segilima & 1,8 & 1,5 & Segilima \\
\hline \multirow[b]{2}{*}{4} & 1 & 0,6 & 0,3 & Bulat & 1,2 & 0,7 & Segilima & 1,4 & 1,2 & Segilima & 1,6 & 1,5 & Segilima \\
\hline & 2 & 0,6 & 0,3 & Bulat & 1 & 0,5 & Segilima & 1 & 1,1 & Segilima & 1,3 & 1,2 & Segilima \\
\hline 5 & 1 & 1,1 & 1,2 & Bulat & 1 & 1,2 & Segilima & 1,3 & 1,2 & Segilima & 1,6 & 1,5 & Segilima \\
\hline
\end{tabular}

- Perbedaan ukuran dan bentuk kuncup

Ukuran kuncup selama empat minggu pengamatan semua kuncup dalam varietas menunjukkan adanya pertambahan ukuran baik pada panjang dan diameter. Bentuk kuncup mengalami perubahan dari minggu ke-1 sampai minggu ke-4. Pada varietas 1 dan 2 minggu pertama kuncup berbentuk bulat, minggu kedua kuncup berbentuk bulat, minggu ketiga kuncup berbentuk segi lima dan minggu keempat kuncup berbentuk segi lima. Pada varietas 3,4 dan 5 minggu pertama kuncup berbentuk bulat, minggu kedua kuncup berbentuk segi lima, minggu ketiga kuncup berbentuk segi lima dan minggu keempat kuncup berbentuk segi lima. Pertambahan ukuran dan perubahan bentuk 
memang terjadi selama proses pembungaan. Hal ini sesuai dengan Hidayat (2010) yang menyebutkan selama proses perkembangan bunga terjadi perubahan ukuran dan bentuk organ bunga.

- Perubahan warna bunga ketika bunga kuncup sampai rontok setiap varietas

Hasil pengamatan menunjukkan bahwa semua varietas dalam proses pembungaan mengalami perubahan warna mulai dari kuncup sampai rontok. Pada tahapan kuncup varietas 2 (kuntum 1 dan 2), varietas 3 (kuntum 1 dan 2) dan varietas 4 (kuntum 1 dan 2) memiliki kesamaan warna kuncup yaitu hijau kuning $(2,5$ gy 8/4) cerah. Warna kuncup varietas 1 (kuntum 1 dan 2) adalah hijau kuning brilian (2,5 gy 8/8). Warna kuncup varietas 5 adalah merah keabuan $(2,5 \mathrm{r}$ 4/6). Saat memasuki tahapan kuncup besar semua varietas mengalami perubahan warna. Varietas 1 (kuntum 1 dan 2) kuncup besar berwarna hijau kuning terang (5 gy 7/8). Varietas 2 (kuntum 1 dan 2) kuncup besar berwarna hijau kuning lembut (2,5 gy 7/6). Varietas 3 (kuntum 1 dan 2) kuncup besar berwarna hijau kuning brilian (2,5 gy 8/8). Varietas 4 (kuntum 1 dan 2) kuncup besar berwarna hijau kuning brilian (2,5 gy 8/8). Varietas 5 kuncup besar berwarna merah lembut (2,5 r 5/8).

Warna bunga $H$. coronaria mengalami perubahan ditahap mulai mekar dan mekar sempurna pada warna korona dan korolanya. Varietas 1 (kuntum 1 dan 2) memiliki korola berwarna kuning (5 y 8/6) dengan korona berwarna pink gelap $(2,5 \mathrm{r}$ 6/8) pada tahap mulai mekar. Korola berwarna kuning (5 y 8/6) dan korona berwarna pink terang (2,5 r 7/8) pada tahap mekar sempurna. Pada tahapan rontok korola berwarna kuning $(2,5$ y $8 / 6)$ dan korona berwarna pink terang (2,5 r 7/8).

Tahapan mulai mekar dan mekar sempurna varietas 2 (kuntum 1) korola berwarna hijau kuning cerah (2,5 gy 8/6) dengan garis madu pink gelap (2,5 $\mathrm{r} 6 / 8)$ dan korona berwarna merah lembut $(2,5 \mathrm{r}$ 5/8). Pada varietas 2 (kuntum 2) korola berwarna hijau kuning cerah $(2,5$ gy 8/6) dengan garis madu pink terang $(2,5 \mathrm{r} 7 / 8)$ dan korona berwarna merah lembut (2,5 r 5/8). Varietas 2 (kuntum 1 dan 2) pada tahapan rontok korola berwarna putih cream $(2,5$ y $8 / 4)$ dengan garis madu merah cerah $(5 \mathrm{r}$ $7 / 8)$ dan korona berwarna merah lembut $(2,5 \mathrm{r}$ $5 / 8)$.

Tahapan mulai mekar varietas 3 (kuntum 1 dan 2) korola berwarna merah lembut $(2,5 \mathrm{r}$ $5 / 8)$ dan korona berwarna merah lembut $(2,5 \mathrm{r}$ $5 / 8$ ). Tahapan mekar sempurna varietas 3 (kuntum 1 dan 2) korola berwarna merah lembut $(2,5 \mathrm{r}$ 8/4) garis madu merah lembut (2,5 r 4/8) dan korona berwarna merah (5 r 4/6). Varietas 3 (kuntum 1) pada tahapan rontok korola berwarna merah lembut (2,5 $\mathrm{r}$ 8/4) dengan garis madu pink keabuan (2,5 r 8/2), pada kuntum 2 korola berwarna merah lembut (2,5 r 8/4) dengan garis madu merah lembut (2,5 r 8/4). Warna korona varietas 3 (kuntum 1 dan 2) berwarna merah (5 r 4/6).

Tahapan mulai mekar varietas 4 (kuntum 1 dan 2) korola berwarna hijau kuning cerah $(2,5$ gy 8/4) dengan garis madu pink lembut $(2,5 \mathrm{r}$ 8/4) dan korona berwarna hijau kuning cerah (2,5 gy 8/6). Tahapan mekar sempurna varietas 4 (kuntum 1 dan 2) korola berwarna hijau kuning cerah $(2,5$ gy $8 / 4$ dan 2,5 gy $8 / 6)$ dan korona hijau kuning cerah $(2,5$ gy $8 / 6)$. Varietas 4 (kuntum 1) pada tahapan rontok korola berwarna hijau kuning pucat (2,5 gy 8/2), kuntum 2 korola berwarna hijau kuning cerah (2,5 gy 8/4). Warna korona varietas 4 (kuntum 1 dan 2) berwarna hijau kuning cerah $(2,5$ gy $8 / 6)$.

Tahapan mulai mekar dan mekar sempurna varietas 5 menunjukkan tidak ada perbedaan warna. Varietas 5 di tahapan mulai mekar dan mekar sempurna memiliki korola berwarna merah merah lembut $(2,5 \mathrm{r}$ 4/8) dan korona berwarna merah keabuan (2,5 r 4/6). Pada tahapan rontok korola berwarna merah lembut $(2,5 \mathrm{r}$ 4/8) dan korola berwarna merah keabuan $(2,5 \mathrm{r} \mathrm{4/6)}$.

Perubahan warna memang terjadi selama tahap kuncup sampai rontok dan merupakan hal alami yang terjadi selama proses pembungaan. Jamsari et al. (2007) yang menyebutkan bahwa dalam pembungaan terjadi perubahan warna pada setiap fase pembungaan. Pada tahapan mulai mekar, mekar sempurna serta rontok varietas 1 dan 5 menunjukkan tidak adanya perubahan warna baik pada korona maupun 
korola. Namun, varietas 2, 3 dan 4 menunjukkan adanya perubahan warna. Varietas 2 (kuntum 1 dan 2) perubahan warna terjadi di tahapan rontok, sedangkan di tahapan mulai mekar dan mekar sempurna tidak terdapat perubahan warna. Varietas 3 (kuntum 1 dan 2) perubahan warna terjadi di tahapan mulai mekar, mekar sempurna dan rontok. Di tahapan mulai mekar tidak terdapat garis madu pada korola, namun ketika memasuki mekar sempurna garis madu mulai muncul. Saat rontok terjadi perubahan warna garis madu korola pada kuntum 1, garis madu mula-mula berwarna merah lembut berubah menjadi keabuan. Varietas 4 (kuntum 1 dan 2) terjadi perubahan warna di tahapan mulai mekar, mekar sempurna dan rontok. Pada mulai mekar terdapat garis madu di korola, namun memudar di tahapan mekar sempurna dan rontok. Selama proses mulai mekar sampai rontok perubahan warna terjadi pada korola. Perubahan warna meliputi terbentuk dan memudarnya warna garis madu korola serta perubahan pada korola itu sendiri.

Berdasarkan hasil pengamatan perubahan warna selama proses pembungaan dapat diketahui bahwa kelima varietas yang diamatimerupakan $H$. coronaria dengan varietas berbeda. Penentuan varietas ini berdasarkan pada warna setiap varietas yang saling berbeda. Warna pada bunga dianggap sebagai pembeda varietas. Warna bunga yang berbeda bukan merupakan variasi perubahan warna selama proses mekarnya bunga. Setiap varietas menunjukkan warna yang berbeda di tahapan mekar sempurna. Varietas 1 memiliki korola kuning tanpa garis madu, korona pink gelap. Varietas 2 memiliki korola hijau kuning cerah dengan garis madu pink gelap, korona merah lembut. Varietas 3 memiliki korola merah lembut dengan garis madu merah lembut, korona merah lembut. Varietas 4 memiliki korola hijau kuning cerah dengan garis madu pink lembut, korona hijau kuning cerah. Varietas 5 memiliki korola merah lembut tanpa garis madu, korona merah keabuan.

\section{KESIMPULAN}

Berdasarkan hasil penelitian yang telah dilakukan dapat disimpulkan sebagai berikut: Proses pembungaan dari 5 varietas $H$. coronaria menunjukkan ada perbedaan pada jumlah kuncup bunga yang muncul dan jumlah kuncup yang berhasil mekar, waktu terjadinya tahap pembungaan, lama hari perkembangan bunga mulai dari kuncup sampai rontok, perubahan ukuran dan bentuk kuncup bunga.

Varietas 1 dan 2 memiliki kesamaan jumlah kuncup yang muncul yaitu 4 dan berhasil mekar 2 bunga. Varietas 3 memiliki 5 kuncup dan berhasil mekar 2. Varietas 4 memiliki 3 kuncup dan berhasil mekar 2. Varietas 5 memiliki 2 kuncup dan berhasil mekar 1.Varietas yang pertama kali muncul kuncup dan berhasil mekar berturut-turut adalah varietas 1, 2, 3, 4, dan 5 . Varietas dengan perkembangan kuncup terlama adalah varietas 3 kuntum 2. Perkembangan kuncup besar terlama adalah varietas 3 kuntum 1 dan varietas 4 kuntum 2. Tahapan mulai mekar terlama adalah varietas 3. Mekar sempurna terlama adalah varietas 4 kuntum 1 . Tahapan rontok terlama adalah varietas 1 kuntum 1 dan 2.

Setiap varietas selama empat minggu pengamatan kuncup menunjukkan pertambahan panjang tangkai dan diameter kuncup serta juga terjadi perubahan bentuk. Varietas 1 dan 2 selama 4 minggu berturu-turut mengalami perubaan bentuk dari bulat, bulat, segilima dan segilima. Varietas 3, 4 dan 5 selama 4 minggu berturut-turut mengalami perubahan bentuk bulat, segilimia, segilima dan segilima.

Kelima varietas merupakan $H$. coronaria dengan varietas berbeda berdasarkan warna bunga yang berbeda satu sama lain. Varietas 1 memiliki korola kuning tanpa garis madu, korona pink gelap. Varietas 2 memiliki korola hijau kuning cerah dengan garis madu pink gelap, korona merah lembut. Varietas 3 memiliki korola merah lembut dengan garis madu merah lembut, korona merah lembut. Varietas 4 memiliki korola hijau kuning cerah dengan garis madu pink lembut, korona hijau kuning cerah. Varietas 5 memiliki korola merah lembut tanpa garis madu, korona merah keabuan. 
Tabel 7. Perubahan warna bunga $H$. coronaria dari kuncup sampai rontok

\begin{tabular}{|c|c|c|c|c|c|c|c|c|c|c|}
\hline \multirow{2}{*}{ Var. } & \multirow{2}{*}{ Kuntum } & \multirow{2}{*}{ Kuncup } & \multirow{2}{*}{ Kuncup Besar } & \multicolumn{2}{|c|}{ Mulai Mekar } & \multicolumn{2}{|c|}{ Mekar Sempurna } & \multicolumn{2}{|c|}{ Mulai Layu } & \multirow{2}{*}{ Rontok } \\
\hline & & & & Korola & Korona & Korola & Korona & Korona & Korola & \\
\hline \multirow{2}{*}{1} & 1 & $\begin{array}{l}\text { Hijau kuning } \\
\text { brilian }\end{array}$ & $\begin{array}{l}\text { Hijau kuning } \\
\text { terang }\end{array}$ & $\begin{array}{c}\text { Kuning } \\
\text { Tanpa GM* }\end{array}$ & Pink gelap & $\begin{array}{c}\text { Kuning } \\
\text { Tanpa GM* }\end{array}$ & Pink terang & $\begin{array}{c}\text { Kuning } \\
\text { Tanpa GM* }\end{array}$ & Pink terang & $\begin{array}{l}\text { Menguncup kembali dan } \\
\text { berwarna hitam }\end{array}$ \\
\hline & 2 & $\begin{array}{l}\text { Hijau kuning } \\
\text { brilian }\end{array}$ & $\begin{array}{l}\text { Hijau kuning } \\
\text { terang }\end{array}$ & $\begin{array}{c}\text { Kuning } \\
\text { Tanpa GM* }\end{array}$ & Pink gelap & $\begin{array}{c}\text { Kuning } \\
\text { Tanpa GM* }\end{array}$ & Pink terang & $\begin{array}{c}\text { Kuning } \\
\text { Tanpa GM* }\end{array}$ & Pink terang & $\begin{array}{l}\text { Menguncup kembali dan } \\
\text { berwarna hitam }\end{array}$ \\
\hline \multirow{2}{*}{2} & 1 & $\begin{array}{l}\text { Hijau kuning } \\
\text { cerah }\end{array}$ & $\begin{array}{l}\text { Hijau kuning } \\
\text { lembut }\end{array}$ & $\begin{array}{c}\text { Hijau kuning } \\
\text { cerah } \\
\text { GM}^{*} \text { pink gelap }\end{array}$ & Merah lembut & $\begin{array}{c}\text { Hijau kuning } \\
\text { cerah }\end{array}$ & Merah lembut & $\begin{array}{l}\text { Putih cream } \\
\text { GM* merah } \\
\text { cerah }\end{array}$ & Merah lembut & Langsung rontok \\
\hline & 2 & $\begin{array}{l}\text { Hijau kuning } \\
\text { cerah }\end{array}$ & $\begin{array}{l}\text { Hijau kuning } \\
\text { lembut }\end{array}$ & $\begin{array}{c}\text { Hijau kuning } \\
\text { cerah } \\
\mathrm{GM}^{*} \text { pink terang }\end{array}$ & Merah lembut & $\begin{array}{c}\text { Hijau kuning } \\
\text { cerah } \\
\text { GM }^{*} \text { pink terang }\end{array}$ & Merah lembut & $\begin{array}{l}\text { Putih cream } \\
\text { GM* merah } \\
\text { cerah }\end{array}$ & Merah lembut & Langsung rontok \\
\hline \multirow{2}{*}{3} & 1 & $\begin{array}{l}\text { Hijau kuning } \\
\text { cerah }\end{array}$ & $\begin{array}{l}\text { Hijau kuning } \\
\text { brilian }\end{array}$ & $\begin{array}{l}\text { Merah lembut } \\
\text { Tanpa GM* }\end{array}$ & Merah lembut & $\begin{array}{c}\text { Merah lembut } \\
\text { GM* Merah } \\
\text { lembut }\end{array}$ & Merah & $\begin{array}{c}\text { Merah lembut } \\
\text { GM* Pink } \\
\text { keabuan }\end{array}$ & Merah & Langsung rontok \\
\hline & 2 & $\begin{array}{l}\text { Hijau kuning } \\
\text { cerah }\end{array}$ & $\begin{array}{l}\text { Hijau kuning } \\
\text { brilian }\end{array}$ & $\begin{array}{c}\text { Merah lembut } \\
\text { Tanpa GM* }\end{array}$ & Merah lembut & $\begin{array}{c}\text { Merah lembut } \\
\text { GM* Merah } \\
\text { lembut }\end{array}$ & Merah & $\begin{array}{c}\text { Merah lembut } \\
\text { GM}^{*} \text { Merah } \\
\text { lembut }\end{array}$ & Merah & Langsung rontok \\
\hline \multirow{2}{*}{4} & 1 & $\begin{array}{l}\text { Hijau kuning } \\
\text { cerah }\end{array}$ & $\begin{array}{l}\text { Hijau kuning } \\
\text { brilian }\end{array}$ & $\begin{array}{c}\text { Hijau kuning } \\
\text { cerah } \\
\text { GM* Pink } \\
\text { lembut }\end{array}$ & $\begin{array}{l}\text { Hijau kuning } \\
\text { cerah }\end{array}$ & 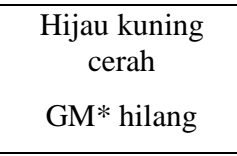 & $\begin{array}{l}\text { Hijau kuning } \\
\text { cerah }\end{array}$ & $\begin{array}{c}\text { Hijau kuning } \\
\text { pucat } \\
\text { GM* hilang }\end{array}$ & $\begin{array}{l}\text { Hijau kuning } \\
\text { cerah }\end{array}$ & Langsung rontok \\
\hline & 2 & $\begin{array}{l}\text { Hijau kuning } \\
\text { cerah }\end{array}$ & $\begin{array}{l}\text { Hijau kuning } \\
\text { brilian }\end{array}$ & $\begin{array}{c}\text { Hijau kuning } \\
\text { cerah } \\
\text { GM* Pink } \\
\text { lembut } \\
\end{array}$ & $\begin{array}{l}\text { Hijau kuning } \\
\text { cerah }\end{array}$ & 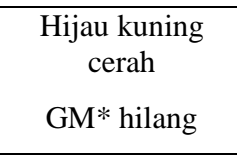 & $\begin{array}{l}\text { Hijau kuning } \\
\text { cerah }\end{array}$ & 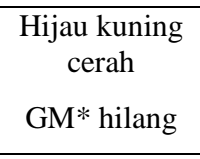 & $\begin{array}{l}\text { Hijau kuning } \\
\text { cerah }\end{array}$ & Langsung rontok \\
\hline 5 & 1 & Merah keabuan & Merah lembut & $\begin{array}{c}\text { Merah lembut } \\
\text { Tanpa GM* }\end{array}$ & $\begin{array}{c}\text { Merah } \\
\text { keabuan }\end{array}$ & $\begin{array}{c}\text { Merah lembut } \\
\text { Tanpa GM* }\end{array}$ & Merah keabuan & $\begin{array}{c}\text { Merah lembut } \\
\text { Tanpa GM* }\end{array}$ & Merah keabuan & Langsung rontok \\
\hline
\end{tabular}

Keterangan: $\mathrm{GM}^{*}=$ Garis madu 


\section{DAFTAR PUSTAKA}

Anggraini DR. 2008. Aneka Tanaman Hias Bangka Belitung yang Menarik. UBB Press, Bangka.

Ardie SW. 2006. Pengaruh Intensitas Cahaya dan Pemupukan terhadap Pertumbuhan dan Pembungaan Hoya diversifolia Blume. Tesis. Institut Pertanian Bogor, Bogor.

Arteca RN. 1995. Plant Growth Subtances; Principles and Application. New York: Chapman \& Hall.

Ashari S. 1998. Pengantar Biologi Reproduksi Tanaman. PT. Rineka Cipta, Jakarta.

Basuki N, Harijono, Kuswanto, Damanhuri. 2005. Studi Pewarisan Antosianin pada Ubi Jalar. J Agravita. 27 (1): 63-68.

Graciosa CN. 2009. Pengaruh Perlakuan Panjang Hari dan Suhu Terhadap Pembungaan Gompherna leontopiodes dan Ptilotus axillaris. Skripsi. Institut Pertanian Bogor, Bogor.

Henuhili V. 2007. Pewarisan Warna Bunga pada Anggrek. Seminar Nasional MIPA. FMIPA UNY, Yogyakarta.

Hidayat Y. 2010. Perkembangan Bunga dan Kuntum pada Tegakan Benih Surian (Toona sinensis Roem). J Agrikultural. 21 (1): 1320.

Jamsari, Yaswendri, Kasim M. 2007. Fenologi Perkembangan Bunga dan Kuntum Spesies Uncaria gambir. Biodiversitas. 8(2): 141146.

Kelijn D, Donkelaar RV. 2001. Notes on The Taxonomy and Ecology of The Genus Hoya (Asclepiadaceae) in Central Sulawesi. $J$ Blumea. 46: 457-483.

Kissinger, Zuhud EAM, Darusman EK, Siregar IZ. 2013. Keanekaragan Jenis Tumbuhan Obat dari Hutan Kerangas. J Hutan Tropis.1 (1): $17-23$.

Mardi T. 2009. Si Cantik Berselimut Lilin. http://agrina-online.com [19 Maret 2015].

Mindari W, Priyadarsini R. 2011. Panduan Praktikum Kimia Tanah. UPN Veteran, Surabaya.
Rahayu S, Trisnawati DE, Qoyim I. 2007. Biologi Bunga Picis Kecil (Hoya lacunosa B1.) di Kebun Raya Bogor. J Biodiversitas. 8 (1): 7-11.

Rahayu S. 2001. Keanekaragaman Genetik Hoya (Asclepiadaceae) Asal Sumatra. Tesis. Institut Pertanian Bogor, Bogor.

Rahayu S. 2006. Keanekaragaman Jenis Hoya (Asclepiadaceae) di Hutan Lindung Bukit Batikap, Kalimantan Tengah. $J$ Biodiversitas. 7 (2): 139-142.

Rahayu S. 2012. Potensi dan Konservasi JenisJenis Hoya Dataran Tinggi Pulau Jawa. $J$ Berkala Penelitian Hayati.18:1-7.

Sandra E. 2005. Membuat Anggrek Rajin Berbunga. AgroMedia Pustaka, Jakarta.

Stead AD. 1992. Pollination-induced flower senescence: a review. Plant growth regulation. 11: 13-20.

Tyas PS, Setyati D, Umiyah. 2013. Perkembangan Pembungaan Lengkeng (Dimocarpus longan Lour) Diamond river. Ilmu Dasar. 14 (2): 111.

Tyler G. 2001. Relationship Between Climate and Flowering of Eight Herbs in a Swedish Decidious Forest. Annals of Botany 87: 623 -630 .

Whitten AJ, Anwar J, Damanik SJ, Hisyamin N. 1984. Ekologi Ekosistem Sumatra. Gadjah Mada University Press, Yogyakarta. 